\title{
Raising Fisheries Development Program Evaluation in The District Lingga Riau Islands Province
}

\author{
Desi Waryanti ${ }^{1}$, Kismartini ${ }^{2}$, Triyuniningsih ${ }^{3}$ \\ Master of Administrative Sciences, Diponegoro University \\ Email: desi.waryanti0912@gmail.com ${ }^{1}$, kis_martini@yahoo.co.id ${ }^{2}$, \\ triyuniningsih67@yahoo.co.id ${ }^{2}$
}

(Received: July 25-2019; revised: November 28-2019; published: December 31-2019)

\begin{abstract}
This study aimed to analyze the evaluation of aquaculture development program in the District Lingga Riau Islands province with output policy indicators and policy outcomes. This research is a descriptive qualitative research. Research site located in the District Lingga Riau Islands province with informants (1) Head aquaculture Marine and Fisheries Agency of Riau Islands province; (2) The chairman, secretary and members of the technical team; (3) Extension of fishery labor contract; (4) The Board pokdakan, then the secondary data, documents, and statistical data. Collection technique used is the technique of in-depth interviews (in-depth interview), observation, documentation, and literature. Engineering validation test data in this study using the technique of triangulation of data, with data analysis techniques of data reduction, data presentation, and draw conclusions (verification). Results showed that the implementation of the program is not maximized especially at the stage of monitoring, coaching and mentoring. Then the program implementation performance is still low. Advice can be given is to improve the monitoring system, the appointment of a companion with consideration of domicile, and coaching and training routine.
\end{abstract}

Keywords :Evaluation of the program, the Program Implementation, Program Development

\section{INTRODUCTION}

Aquaculture Development Program is one of the strategic program Riau Islands provincial government to support business development in the field of fish farming and aquaculture optimize resource utilization, with the purpose of the activities is to increase production and income, foster entrepreneurship, institutional strengthening and improving environmental groups. The program is based on the Riau Islands Provincial Regulation No. 6 of 2006 on Marine Enterprises which urged that the regional resource use must be made in efficient and effective manner. One of the districts in Riau Islands province who runs this program is Lingga District. Aquaculture development program in the District Lingga, implemented by providing assistance / grant Keramba cage (KJA) HDPE to fishermen in 2012 and 2013. Through this program, the government actually hope efforts of fish farmers will be more advanced and increased welfare and people's economy will develop well. The indicators to measure the success of efforts pokdakan Aquaculture Development Program recipients are increasing production, improving incomes, and access to financing at a fish farmer group (pokdakan). However, apparently the result of production of fish farmers in the district of Linga can be said not stable even though the district has received aid Aquaculture Development 
174 Jurnal Ilmiah Ilmu Administrasi Publik: Jurnal Pemikiran dan Penelitian Administrasi Publik Volume 9 Number 2,July - December 2019. Page 173-184

Program as shown in the following table: actually the government hopes the effort will be more advanced fish farmers and increased welfare and people's economy will develop well. The indicators to measure the success of efforts pokdakan Aquaculture Development Program recipients are increasing production, improving incomes, and access to financing at a fish farmer group (pokdakan). However, apparently the result of production of fish farmers in the district of Linga can be said not stable even though the district has received aid Aquaculture Development Program as shown in the following table: actually the government hopes the effort will be more advanced fish farmers and increased welfare and people's economy will develop well.

The indicators to measure the success of efforts pokdakan Aquaculture Development Program recipients are increasing production, improving incomes, and access to financing at a fish farmer group (pokdakan). However, apparently the result of production of fish farmers in the district of Linga can be said not stable even though the district has received aid Aquaculture Development Program as shown in the following table: The indicators to measure the success of efforts pokdakan Aquaculture Development Program recipients are increasing production, improving incomes, and access to financing at a fish farmer group (pokdakan). However, apparently the result of production of fish farmers in the district of Linga can be said not stable even though the district has received aid Aquaculture Development Program as shown in the following table: The indicators to measure the success of efforts pokdakan Aquaculture Development Program recipients are increasing production, improving incomes, and access to financing at a fish farmer group (pokdakan). However, apparently the result of production of fish farmers in the district of Linga can be said not stable even though the district has received aid Aquaculture Development Program as shown in the following table:

Table 1

Total production of Aquaculture in the District Lingga

\begin{tabular}{|c|c|c|c|c|}
\hline \multirow{2}{*}{ No. } & \multirow{2}{*}{ Year } & \multicolumn{3}{|c|}{ Type } \\
\cline { 3 - 5 } & & sea & bargain & Brackish \\
\hline 1 & 2015 & 400.84 & 9.04 & 22.98 \\
\hline 2 & 2016 & 118.78 & 18.81 & 0.13 \\
\hline 3 & 2017 & 2.36 & 18.06 & 20.87 \\
\hline
\end{tabular}

Source: Department of Marine and Fisheries LAKIP Riau Islands province, 2018

Then, the level of prosperity of the farmers in the district Linga can also be said to be still lacking, this is caused by lack of access to capital, markets and technology, social protection culture, no assets as active capital, the poor quality of the environment as well as weak institutional business group of marine and fisheries, including group fish farmers (pokdakan). Some of these problems are also found in previous studies related to the implementation of the Development of Fish Cultivation in Keramba cage in Maninjau, West Sumatra, in the results of this evaluation, it is known that the use of floating cages still produce a lot of trash fish feed is wasted that is not environmentally friendly, management of aquaculture in Lake Maninjau is also relatively simple,(Rasidi, Erlania, \& Prasetio, 2010), Then, the results of research Wahyuni 
et al, in a study Evaluation Program Aquaculture Development in Batu, program development of aquaculture can provide a less than optimal in terms of fish production and prosperity of farmers due to weak institutions farmers, allocation of funds according to needs, and marketing difficulties resulting from cultivation(Wahyuni, Hanafi, and Saleh, 2013)

Noted several problems related to the implementation of the Program Development of Aquaculture in Lingga Regency which was also experienced by other regions as outlined in earlier studies although not in areas of the same, hence the need for further research related to the evaluation of program development of Aquaculture in the District Lingga so that later it can be seen how the implementation of the program and why the implementation of this program has not been maximized (Farida, 2017; Nawir, Maulana, Nuryamin, \& Husain, n.d.; Niswaty, Juniati, Darwis, Salam, \& Arhas, 2019; Syamsiar, Saggaf, Salam, \& Ihsan, 2018)(Langkai, Akib, Musah, \& Naharia, 2016; Simatupang \& Akib, 2011; Smith \& Akib, 2015; Suprapto, Pomalingo, \& Akib, 2018). Evaluation is one stage in public policy (Dunn, 2003, pp. 24-25) in the evaluation are true systemic mindset consists of three (3) components: Input, Process, Output (Sabdaningtyas, 2018), In the public policy there is also the implementation stage (Purwanto \& Sulistiyastuti, 2012) explains that the core of the implementation phase is an activity to distribute the output of the policy (to deliver policy outputs) conducted by the implementor to target groups (target groups) in an effort to realize the objectives of the policy, which in its evaluation can use two (2) output indicators ( policy outputs) and impact indicators (Policy outcomes). For research related to program evaluation, researchers used the policy theory output(Ripley \& Franklin, 1968)where in evaluating a program, can use indicators output indicators consisting of: (a) access, (b) Scope, (c) Frequency, (d) Bias / Distortion, (e) the accuracy of the Service, (f) Compliance program with needs. The theory of policy outputs can be used to determine the direct consequence received or perceived by the target group of the realization of an activity or program (Hariani, 2017),

Departing from the problems and theories that have later this study will examine how the evaluation of the implementation of the program development of aquaculture in the District Lingga Riau Islands province and how the real impact on the development of aquaculture in the District Lingga Riau Islands province where the research has not been conducted in the district, so this research is research that is new to the district Lingga.

\section{METHOD}

The approach used in the study is a qualitative research, because the problem of the dynamic nature of this study, which according Singarimbun (Sugiyono, 2009)Qualitative methods are used to the problems that remain unclear, the little population and the limited area coverage, while descriptive used to measure carefully to uncover phenomena that exist in the field and develop concepts and collect data and facts, but does not test the hypothesis. The approach used next is the type of approach used descriptive perspective is the perspective of formal evaluation. Research site located in the district taken Lingga Riau Islands province with study sites Medang Island Village, District Senayang, because the village is a village, which is supported aquaculture development programs in the form of grants Keramba cage in 2012-2013. The data used in this research is primary data obtained directly from informants consisting of: 
176 Jurnal Ilmiah Ilmu Administrasi Publik: Jurnal Pemikiran dan Penelitian Administrasi Publik Volume 9 Number 2,July - December 2019. Page 173-184

(1) Head aquaculture Marine and Fisheries Agency of Riau Islands province; (2) The chairman, secretary and members of the technical team; (3) Extension of fishery labor contract; (4) The Board pokdakan. Determination of informants in this study using purposive sampling technique, the technique of determining the informant in a way been directly according to the research objectives(Afifuddin \& Beni, 2009), Then the secondary data obtained through documents grouped data, production data and revenue fish farmers who are members of pokdakan and other official documents, then the data obtained from statistical data Aquaculture Marine and Fisheries Agency of Riau Islands province. Collection technique used is the technique of indepth interviews (in-depth interview), observation, documentation, and literature. While the data validation testing technique(Bungin, 2015) in this study using triangulation techniques of data, with data analysis techniques of data reduction, data presentation, and drawing conclusions (verification) (Miles, Huberman, and Saldana, 2014).

\section{RESULT AND DISCUSSION}

Aquaculture Development Program is one of the strategic program Riau Islands provincial government to support business development in the field of fish farming and aquaculture optimize resource utilization, with the purpose of the activities is to increase production and income, foster entrepreneurship, institutional strengthening and improving environmental groups. Aquaculture Development Program being implemented in some counties and cities in the province of Riau Islands one of them in the district of Linga. This program has been implemented in Lingga District since 2012.

The main components of Aquaculture Development Program activities in the District Lingga is channeling aid Keramba cage (KJA) HDPE, as an effort to increase the production of marine fish farming. In 2012 this program has collected as many as 20 (twenty) heads of household who are members of one (1) pokdakan beneficiary form Keramba cage (KJA), then in 2013 the number of heads of families in pokdakan acceptance of assistance increased by 20 (twenty) Head of the family consisting of 2 (two) pokdakan beneficiary Keramba cage, bringing the total pokdakan who have received the benefits of aquaculture development program in the form of Keramba cage for three (3) pokdakan. Keramba cage, which was given to 40 (forty) of fish farmers is composed of 80 (eighty) swath cages $3 \times 3$ meters each needs plots where the whole plot is centralized in one place and each member is responsible for the care of two (2) swath cages, then in 2013 the number of heads of families in pokdakan acceptance of assistance increased by 20 (twenty) Head of the family consisting of 2 (two) pokdakan beneficiary Keramba cage, bringing the total pokdakan who have benefited from the program development of aquaculture in the form of cages Floating net 3 (three) pokdakan. Keramba cage, which was given to 40 (forty) of fish farmers is composed of 80 (eighty) swath cages $3 \times 3$ meters each needs plots where the whole plot is centralized in one place and each member is responsible for the care of two (2) swath cages.

Then in 2013 the number of heads of families in pokdakan acceptance of assistance increased by 20 (twenty) Head of the family consisting of 2 (two) pokdakan beneficiary Keramba cage, bringing the total pokdakan who have benefited from the program development of aquaculture in the form of cages Floating net 3 (three) pokdakan. Keramba cage, which was 
given to 40 (forty) of fish farmers is composed of 80 (eighty) swath cages $3 \times 3$ meters each needs plots where the whole plot is centralized in one place and each member is responsible for the care of two (2) swath cages, bringing the total pokdakan who have received the benefits of aquaculture development program in the form of Keramba cage for three (3) pokdakan. Keramba cage, which was given to 40 (forty) of fish farmers is composed of 80 (eighty) swath cages $3 \times 3$ meters each needs plots where the whole plot is centralized in one place and each member is responsible for the care of two (2) swath cages, bringing the total pokdakan who have received the benefits of aquaculture development program in the form of Keramba cage for three (3) pokdakan. Keramba cage, which was given to 40 (forty) of fish farmers is composed of 80 (eighty) swath cages $3 \times 3$ meters each needs plots where the whole plot is centralized in one place and each member is responsible for the care of two (2) swath cages,

The process of implementation of the program development of aquaculture in the District Lingga begins with the preparation from planning to budgeting, at this stage also formed the Technical Committee, comprised of Extension Fisheries Labor Contract (PPTK) 1 (one), in others years, the Technical Team as much as 3 (three people. Then be disseminated to pokdakan in stages. Aquaculture Development Program Socialization Lingga District level held in conjunction with the process of identification, verification and selection of prospective beneficiaries, have been in the absence of specific budget for prospective beneficiaries gather in one place to anticipate these conditions. So socialization is done to prospective beneficiaries are predetermined and resumed at the stage of filing of administrative requirements pokdakan of beneficiaries. Once set anyone pokdakan receiver, then the next is the distribution of aid in accordance with the Decree of the Governor of Riau Islands province, along with the minutes to be taken by the chairman pokdakan, at this stage there is a monitoring system which then continued with the help of guidance and assistance of the Technical Committee.

The implementation of the process then researchers sought to evaluate the process of implementation of the program using the 2 (two) indicators, namely Output Policy and Policy Outcome. In a second evaluation indicators are included in the dimensions of policy performance evaluation, and as a true indicator measuring devices can bersfat narrative and figures(Hariani, 2017), The results obtained from this research with the study site in the village of Medang Island are as follows:

\section{Evaluation of the Policy Indicators Output}

Policy output in a dimension of evaluation presented what is actually done from a program (Poister, 2013), In this study, to see the direct consequences of perceived and experienced by groups of beneficiaries / target in this case is a group of fish farmers (pokdakan) in the district of Linga beneficiaries Aquaculture Development Program assistance in 2012 and 2013. The results of the evaluation of these indicators are as follows:

(a) Access: Access indicator used to see if the implementor can easily be reached by the target when needed (Rachman, 2014), In this component, the study will look at in terms of communication between the implementor with pokdakan to find out information about the program and to submit a complaint if they had experienced problems during the 
178 |Jurnal Ilmiah Ilmu Administrasi Publik: Jurnal Pemikiran dan Penelitian Administrasi Publik Volume 9 Number 2,July - December 2019. Page 173-184

implementation process of Aquaculture Development program. Communication between the implementer with pokdakan while it is still less than the maximum, because the officer escort drawn from extension agents Fisheries Tenga Contract (PPTK) not being in the midst of society although communication via phone or sms can still be done, but the interaction is intense between companion with pokdakan less developed well. If there is a problem,

(b) Scope: Indicators of this scope is used to assess how much of the target group can be reached Aquaculture Development Program in the District Lingga. The yield on this indicator can be said is still low, the percentage of beneficiaries fish farmers in the village of Island Medang when compared with the total number of fish farmers in the district of Lingga each year has a lower percentage. In 2012 the percentage of fish farmers in the village Medang beneficiaries only about $1.77 \%$ and $2.67 \%$ next year, but the figures show no more than $2.67 \%$. This illustrates that the scope or coverage of the program to the population of fish farmers in the district of Lingga still low.

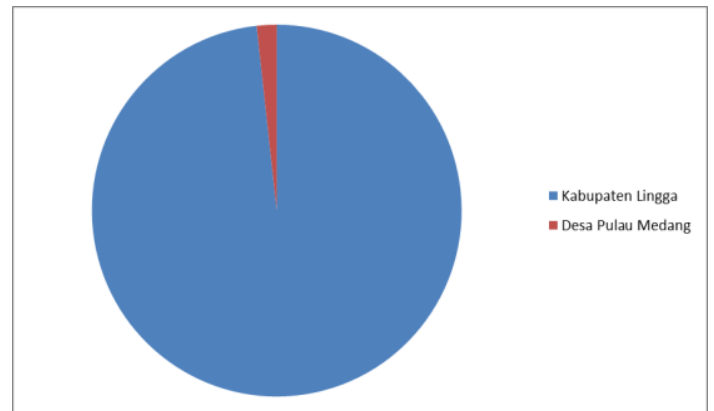

Figure 1.

Scope of Aquaculture Development Program in the District Lingga with Medang Island Village Study Area in 2012 (left) and 2013 (right)

(c) Distortion: This indicator is used to assess whether the services provided by the implementer deviate from a specified target group of Aquaculture Development Program. The yield on these indicators demonstrate that the discovery of bias / distortions in the implementation of the program. One of the requirements of Aquaculture Development Program is the nominee is a community of fishermen / fish farmers who are interested, willing to develop fish farming, and committed to managing the benefit package. However, there are still communities are not fishermen participate merima aid Aquaculture Development Program. The number of people receiving non-fishermen aid amounting to 10 (ten).

(d) Accuracy of Service: What is meant in this indicator is the timely implementation of the program on the disbursement of aid in the program Aquaculture Development Program. On the implementation in 2012 and 2013 aid Aquaculture Development Program submitted to pokdakan in October, in which the moon has entered the rainy season so the fish farming activity mainly enlargement can be run as usual for this business unit's supply required plenty of water and continuously. 
(e) Conformity of the program to the needs: This indicator is used to measure whether the various outputs of Aquaculture Development Program in the District Lingga received by the target group in this case pokdakan is consistent with the requirements or not. Requirements referred to in this context is the need to increase the production of fish farming. Based on the results of observations and interviews to 3 pokdakan beneficiaries of Aquaculture Development Program concluded that the aid granted in the form of aid Keramba cage (KJA) HDPE has been in accordance with the need to increase the production of fish farming. Because since the beginning of the relief is based on the basic needs pokdakan for the development of fish farming.

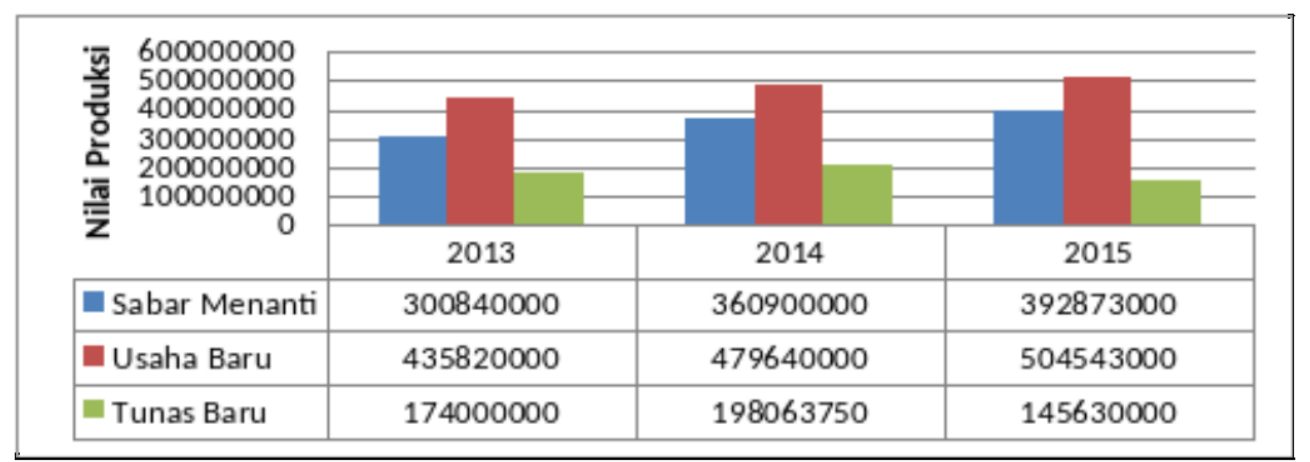

Figure 2.

Production Value graph Pokdakan Beneficiaries Aquaculture Development Program Medang Desa Lingga District in the year 2013 - 2015

Source: Processed researchers

Figure chart 2 shows an increase in the value of fish production in the village Pokdakan Medang. The graph shows the increase after the aid granted, this shows that the program complies with the requirements. But still there is 1 (one) pokdakan which actually declined in 2015, namely pokdakan Tunas Baru.

\section{Outcome Evaluation of the indicator Policy}

Policy outcomes are the results obtained from the program (Poister, 2013), This indicator can be seen from three (3) components: First: initial direct impact or outcome of the implementation of the program; Second: the impact of mid-term or intermediate outcomes; Third: the impact of long-term or long-term outcome. The results showed as follows:

a) Direct Impact (Initial Outcome): This impact is the impact that is felt directly by the target group when receiving assistance from the program, in this study the views from the increase in fisheries production and the average - average incomes of farmers' pokdakan. The existence of these programs have a direct impact in the form of an increase in production value in 2015 Pokdakan although Pokdakan Tunas Baru decreased, even in 
180 Jurnal Ilmiah Ilmu Administrasi Publik: Jurnal Pemikiran dan Penelitian Administrasi Publik Volume 9 Number 2,July - December 2019. Page 173-184

2016 was not found pokdakan production value data is different from the two (2) pokdakan another. However, despite increased sabra pokdakan waiting and new business declined rapidly in 2016. The increase in production was followed by an increase in income as can be seen in the following graph:

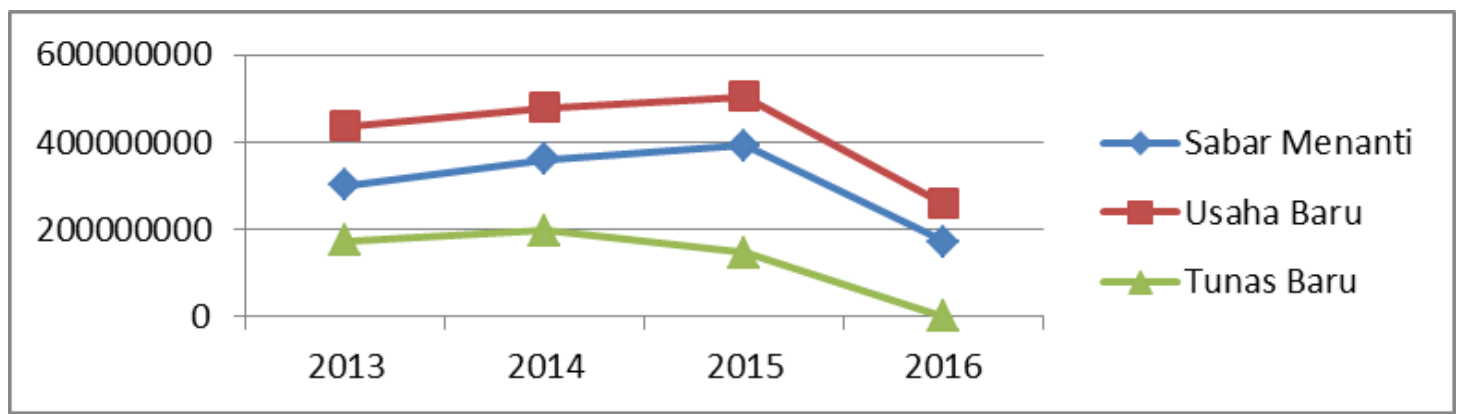

Figure 3.

Graph Pokdakan Aquaculture Production Value in Area Studies Medang Island Village, Lingga District in 2013-2015

Source: Processed researchers

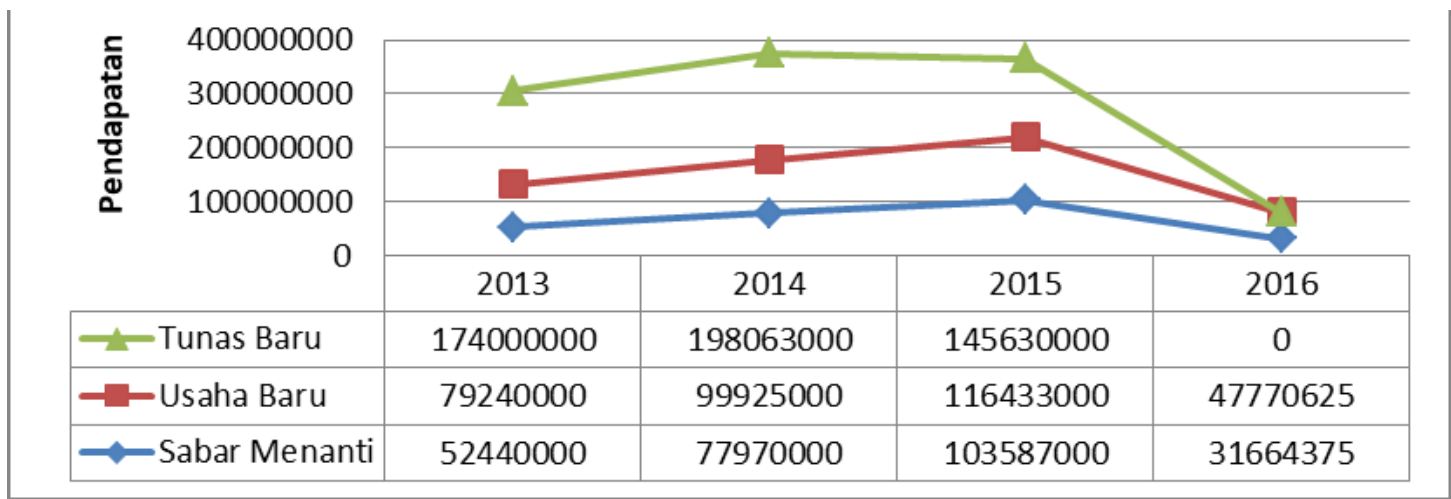

Figure 4.

Graph pokdakan Income levels in Medang Island Village Study Area, Lingga District in 2013-2015

b) Medium Impact (Intermediate Outcome) On the medium-term impact indicators, which in the evaluation consists of two (2) things: 1). The growth of entrepreneurship in the field of aquaculture, where pokdakan have been able to grow market share by expanding the marketing of products, from developing new business units that support the activities of the fisheries industry and started his access to capital from microfinance institutions or banks, as well; 2). Increasing the institutional capacity of the group of fish farmers, where pokdakan has been able to position and its role as a vehicle of learning both for its 
members as well as fish farmers more, pokdakan able to take the role as a vehicle for cooperation between fisheries business and future pokdakan been able to perform its role as social institutions as well as institutions economy.

Table 2.

Business development and capacity pokdakan in Area Studies Medang Island Village Linga District in 2012-2013

\begin{tabular}{|l|l|c|l|l|l|}
\hline No & \multicolumn{1}{|c|}{ Pokdakan } & $\begin{array}{c}\text { Year Received } \\
\text { Help }\end{array}$ & $\begin{array}{c}\text { Pioneering } \\
\text { effort }\end{array}$ & $\begin{array}{c}\text { New Venture } \\
\text { Pokdakan }\end{array}$ & \multicolumn{1}{|c|}{$\begin{array}{l}\text { Capacity } \\
\text { Pokdakan }\end{array}$} \\
\hline 1. & Tunas Baru & 2012 & $\begin{array}{l}\text { enlargement } \\
\text { grouper }\end{array}$ & $\begin{array}{l}\text { enlargement } \\
\text { snapper }\end{array}$ & $\begin{array}{l}\text { Savings and } \\
\text { Loan }\end{array}$ \\
\hline 2. & $\begin{array}{l}\text { Patiently } \\
\text { waiting }\end{array}$ & 2013 & $\begin{array}{l}\text { enlargement } \\
\text { snapper }\end{array}$ & There is no & There is no \\
\hline 3. & New venture & 2013 & $\begin{array}{l}\text { enlargement } \\
\text { grouper }\end{array}$ & There is no & There is no \\
\hline
\end{tabular}

Source: processed researchers

Table 2 shows that the secondary effects of this program does not appear on pokdakan Sabar Menanti and New Business, otherwise the impact is felt by Pokdakan Tunas Baru, pokdakan is able to develop a new business venture that enlargement snapper and micro-credit. Tunas Baru Pokdakan also able to increase institutional capacity in the form of savings and loans institutions managed by the pokdakan with the aim of meeting the needs of member pokdakan. While pokdakan Sabar Menanti and New Venture does not happen the development of business and strengthening institutional capacity pokdakan, is caused by high feed prices, so that the crop unprofitable because of high operating costs. While strengthening the institutional capacity of pokdakan Sabar Menanti and New Business does not exist,

Impact Long (Long-term Outcome): This impact seen from the extent to which pokdakan pokdakan able to become a prosperous and independent. So far the long-term impact has not been visible. Pokdakan members' income is not significant in the long term even some groups temporarily cease due to the dry season, then pokdakan also still rely no capital granted by the relevant department and there is no one who can access the program credit (KUR and KKP-E).

\section{CONCLUSION}

The results showed that the implementation of aquaculture development program in the District Lingga Riau Islands Province conducted since 2012 and still not up because there are 
182 | Jurnal Ilmiah Ilmu Administrasi Publik: Jurnal Pemikiran dan Penelitian Administrasi Publik Volume 9 Number 2,July - December 2019. Page 173-184

some components in the output policy indicators and policy outcomes is still less than the maximum. In the evaluation result indicator output policy on access components constrained in the presence of a technical team that is not always in the field so as to interrupt the direct communication, the components of the coverage, scope of programs in the study area is low at $1-2 \%$ range, the bias component still seen in this case the recipient is not in accordance with predetermined rules, there are still non-farmers are getting help, sselanjutnya terms of promptness of service of this program has been judged appropriate for the help given during the rainy season so that development activities are carried out as usual, and component conformity of the program with the need also considered appropriate because since the beginning of the relief is based on the basic needs pokdakan for the development of fish farming, While the indicator policy outcomes, indicators direct impact there is an increase in the value of production and revenue although in 2015 Pokdakan Tunas Baru decreased followed by two (2) pokdakan other, the medium-term impact is only felt by 1 (one) pokdakan, next to term impact length of the long-term impact so far has not seen. It can be concluded that the Aquaculture Development Program in the District Lingga by looking at study sites in the Village of Medang Island is not maximized.

\section{REFERENCES}

Afifuddin, \& Beni, A. S. (2009). Metodologi Penelitian Kualitatif. Bandung: Pustaka Setia.

Bungin, B. (2015). Analisis Data Penelitian Kualitatif. Jakarta: Raja Grafindo Persada.

Dunn, W. (2003). Pengantar Analisis Kebijakan Publik. Yogyakarta: Gadjah Mada University Press.

Farida, U. (2017). Analysis of Empowerment Program that was Implemented in Maтuju Regency East Sulawesi Indonesia. 149(Icest), 19-21.

Hariani, N. J. (2017). Evaluasi Kinerja Kebijakan Kesehatan Ibu dan Anak (Studi Evaluasi Policy Output dan Policy Outcome Program Expanding Maternal and Neonatal Survival (EMAS) di Kabupaten Sidoarjo). 5, 1-13.

Langkai, J. E., Akib, H., Musah, C. I., \& Naharia, O. (2016). The Impact of the Implementation Based on the Policy Development Neighborhood for the Social Welfare in the City Of Manado. Mediterranean Journal of Social Sciences, 7(2 S1), 259.

Miles, M. ., Huberman, A. ., \& Saldana, J. (2014). Qualitative Data Analysis, A Methods Sourcebook (3rd ed.; Tjetjep Rohindi Rohidi, ed.). Jakarta: UI-Press.

Nawir, R., Maulana, R., Nuryamin, M., \& Husain, T. (n.d.). Implementation Program of Poor Rice Copyright.

Niswaty, R., Juniati, F., Darwis, M., Salam, R., \& Arhas, S. H. (2019). The Effectiveness of Leadership Functions Implementation in The Makassar Departement of Manpower. JPBM (Jurnal Pendidikan Bisnis Dan Manajemen), 5(1), 1-10. 
Desi Waryanti, Kismartini, Triyuniningsih; Raising Fisheries Development Program... | 183

Poister, T. H. (2013). Measuring Performance in Public and Nonprofit Organizations. JosseyBass.

Purwanto, A., \& Sulistiyastuti. (2012). Implementasi Kebijakan Publik: Konsep dan Aplikasinya di Indonesia. Yogyakarta: Gaya Media.

Rachman, N. A. (2014). Pengukuran Kinerja Implementasi Kebijakan Penanggulangan Kemiskinan di Desa Wisata Brayut. Kebijakan \& Administrasi Publik, 18.

Rasidi, R., Erlania, E., \& Prasetio, A. B. (2010). Evaluasi dan Status Perkembangan Usaha Budidaya Ikan dalam Keramba Jaring Apung di Danau Maninjau, Sumatera Barat. Media Akuakultur. https://doi.org/10.15578/ma.5.1.2010.51-56

Ripley, R. B., \& Franklin, G. (1968). Policy Implementation and Bureaucracy. Chicago: The Dorsey Press.

Sabdaningtyas, L. (2018). Model evaluasi implementasi kebijakan standar pelayanan minimal pada satuan pendidikan jenjang SD. Jurnal Penelitian Dan Evaluasi Pendidikan, 22(1), 70. https://doi.org/10.21831/pep.v22i1.19638

Simatupang, P., \& Akib, H. (2011). Efektivitas Implementasi dan Dampak Kebijakan dalam Konteks Desentralisasi Pemerintahan. Jurnal Ilmiah Ilmu Administrasi Publik, 2(1), 1-9.

Smith, A., \& Akib, H. (2015). The implementation effectiveness of trash management in Ambon, Maluku: The influence of socialization, coordination and control to the effectiveness of trash management. International Journal of Public Administration, $38(10), 683-688$.

Sugiyono. (2009). Metode Penelitian Kuantitatif,Kualitatif, dan R\&D. Bandung: Alfabeta.

Suprapto, S., Pomalingo, N., \& Akib, H. (2018). The implementation of a culture of discipline for the state civil apparatus (ASN) in Gorontalo Regency (A Study of the Application of Discipline Ambassador Vest). 1st International Conference on Social Sciences (ICSS 2018). Atlantis Press.

Syamsiar, S., Saggaf, M. S., Salam, R., \& Ihsan, S. R. (2018). Implementation Of Supervision On Office Of Community Empowerment And Makassar City Village.

Wahyuni, K. D., Hanafi, I., \& Saleh, C. (2013). Evaluasi Program Pengembangan Budidaya Perikanan di Kota Batu. J-Pal, 4(1), 26-37. 
$184 \mid$ Jurnal Ilmiah Ilmu Administrasi Publik: Jurnal Pemikiran dan Penelitian Administrasi Publik Volume 9 Number 2,July - December 2019. Page 173-184 